\title{
BACTERIOCIN LIKE SUBSTANCE PRODUCTION BY CARNOBACTERIUM PISCICOLA IN A CONTINUOUS SYSTEM WITH THREE CULTURE BROTHS. STUDY OF ANTAGONISM AGAINST LISTERIA MONOCYTOGENES ON VACUUM PACKAGED SALMON
}

\author{
Renate P. Schöbitz ${ }^{1 *}$; Pamela A. Bórquez ${ }^{1}$; Marcia E. Costa ${ }^{1}$; Luigi R. Ciampi ${ }^{2}$; Carmen S. Brito ${ }^{1}$ \\ ${ }^{1}$ Instituto de Ciencia y Tecnología de los Alimentos, Facultad de Ciencias Agrarias, Universidad Austral de Chile, Valdivia, \\ Chile; ${ }^{2}$ Instituto de Producción y Sanidad Vegetal, Facultad de Ciencias Agrarias, Universidad Austral de Chile \\ Submitted: May 17, 2004; Returned to authors for corrections: March 22, 2005; Approved: January 30, 2006
}

\begin{abstract}
Three culture media were studied for the bacteriocin like substance (BLS) production from Carnobacterium piscicola L 103 in a batch and continuous culture system. The efficacy of the antagonistic substance against Listeria monocytogenes was tested on vacuum packaged salmon. BLS was produced in a $1.0 \mathrm{~L}$ bioreactor by batch and continuous culture using D-MRS, mod. D-MRS and APT as nutrient broths. Salmon fillets were inoculated with BLS (200 AU mL $\mathrm{md}^{-1}$ and $\left.\mathrm{AU} \mathrm{mL}^{-1}\right)$ and $8.0 \times 10^{1} \mathrm{cfu} \mathrm{cm}^{-2}$ of L. monocytogenes and stored at $4^{\circ} \mathrm{C}$. The growth of L. monocytogenes was determined every 5 days during 15 days. After $12 \mathrm{~h}$ of batch culture the stationary growth phase of $C$. piscicola L 103 started, with a BLS activity of $800 \mathrm{AU} \mathrm{mL}^{-1}$ in D-MRS and mod. D-MRS broth, and of $400 \mathrm{AU} \mathrm{mL}^{-1}$ in APT broth. During continuous culture BLS activity increased to $6400 \mathrm{AU} \mathrm{mL}^{-1}$ in both types of MRS broths, while in APT the activity decreased to $50 \mathrm{AU} \mathrm{mL}^{-1}$, indicating a clear advantage of the first two culture media and also of the continuous culture system. BLS had a bacteriostatic effect on L. monocytogenes when inoculated on salmon, with counts of $6.0 \times 10^{3} \mathrm{cfu}$ $\mathrm{cm}^{-2}$ after 15 days. No significant differences were found between the two BLS activities used. In the control without BLS, L. monocytogenes counts increased to $1.0 \times 10^{6} \mathrm{cfu} \mathrm{cm}^{-2}$ after 15 days of storage.
\end{abstract}

Key words: Carnobacterium piscicola, bacteriocin like substance production, continuous system, Listeria monocytogenes antagonism, vacuum packaged salmon

\section{INTRODUCTION}

Bacteriocins are ribosomally synthesized antibacterial proteins or peptides, active against closely related bacteria (18). Among the lactic acid bacteria (LAB) a high diversity of bacteriocins are produced of which several have been patented for applications in food. However, nisin is currently the only bacteriocin approved for use as a food preservative $(7,16)$. Though bacteriocins are inhibitory against foodborne pathogens, such as Listeria monocytogenes, they are not antibiotics since their synthesis and mechanism of action distinguish them from clinical antibiotics (7).

Among the LAB, several strains of Carnobacterium piscicola produce bacteriocins with antagonistic activity against L. monocytogenes $(11,14)$. This human pathogen is of mayor concern in the food industry, in particular in the salmon processing plants, where L. monocytogenes is frequently isolated $(12,19)$.

The application of bacteriocins or bacteriocin producing LAB strains in food has a potential use as part of the hurdle technology, since bacteriocins have shown synergies with other treatments and could be used as hurdles to improve food safety. The use of antagonistic compounds in food can be especially attractive in minimal processed refrigerated foods, which lack multiple barriers to stop the growth of pathogenic bacteria. Among these foods, salmon constitutes an interesting foodmatrix for the study of the effectivenes of antilisterial bacteriocins.

*Corresponding Author. Mailing address: Avda. Julio Sarrazín R. - Campus Isla Teja - Casilla 47, Valdivia, Chile. Tel.: (+5663) 221423, Fax: (+5663) 221355. E-mail: rschobit@uach.cl 
When the optimal parameters for the BLS production are determined, it is necessary to know the ideal growth conditions of the lactic strain for the bacteriocin production. The composition of the culture medium could have important effects on the yield of the bacteriocin. Peptone is a fundamental component of culture media, since it influences the bacteriocin production. Other components however, do not have an effect on the production of this metabolite (21). In relation to the culture system for the production of bacteriocin, one of the most widely used techniques is the growth of the microorganisms in batch or continuous culture. These systems require complex media and controlled conditions of $\mathrm{pH}$ and temperature (9). In order to harvest maximal bacteriocin amounts, the fermentation broth is collected as soon as maximum activity is obtained (8). An ideal protocol for bacteriocin production should be one that is applicable to large scale purification, with low production and recovery costs and leading to bacteriocin yields greater than $50 \%$ and purity greater than $90 \%$ (18).

The present study reports the use of different culture media for the production of a bacteriocin like substance (BLS) from $C$. piscicola L 103 in a continuous culture system. Furthermore, the antagonistic activity of the BLS against $L$. monocytogenes inoculated on salmon was investigated.

\section{MATERIALS AND METHODS}

\section{Bacterial strains and culture media}

The BLS producing strain C. piscicola $\mathrm{L} 103$ described previously (22), was kept frozen at $-20^{\circ} \mathrm{C}$ in brain heart infusion broth supplemented with $1 \%$ glycerol. As indicator strain for the BLS assays and fish inoculation experiment, L. monocytogenes Lm82 (Food and Drug Administration, Washington D.C.) was used. During the study the indicator strain was stored at $4 \pm$ $2^{\circ} \mathrm{C}$ in cooked meat medium broth (CMM, Difco) and subcultured twice in tryptic soy broth (Difco) before use.

Three culture media were evaluated: a) D-MRS broth, which is MRS broth (Difco) without acetate and glucose, but with 20 $\mathrm{g}$ of sucrose added per liter (21) and with the $\mathrm{pH}$ adjusted to 6.5; b) modified D-MRS broth, which is MRS broth without acetate and glucose and without meat extract, but with $20 \mathrm{~g} / \mathrm{L}$ of sucrose and $20 \mathrm{~g} / \mathrm{L}$ of proteose peptone $\mathrm{N}^{\circ} 3$ (21) and the $\mathrm{pH}$ adjusted to $6.5 ; \mathrm{c})$ APT broth (Difco).

\section{Continuous culture for BLS production}

A 1.0 L modular bioreactor (Gallenkamp) was used for growth and BLS production of C. piscicola $\mathrm{L} 103$. The $\mathrm{pH}$ of the culture broth was maintained at 6.5 with $3 \mathrm{~N} \mathrm{NaOH}$ during fermentation. The broth was inoculated with a $10 \%(\mathrm{v} / \mathrm{v})$ inoculum of an overnight culture of $C$. piscicola $\mathrm{L} 103$. Batch fermentation was performed at $25^{\circ} \mathrm{C}$ with agitation $(150 \mathrm{rpm})$ and an airflow of $550 \mathrm{vm}$ (volume of air per mL of medium). For continuous production, after approximately $26 \mathrm{~h}$ of batch culture in each nutrient broth, the culture was switched to continuous culture by feeding fresh medium at three different dilution rates, calculated from the duplication time of $C$. piscicola L103 in each culture broth during batch fermentation. Steady state was assumed to occur after three residence times. Samples were taken from the bioreactor at different intervals for microscopic control of the culture, determination of BLS activity and optical density reading (O.D.578nm) of the broth. Culture broths with the highest BLS activity during continuous fermentation were selected for further inoculation experiments. The culture supernatant was treated as previously described, and stored frozen at $-18^{\circ} \mathrm{C}$ until use.

\section{Determination of the BLS activity}

The culture supernatant was obtained following centrifugation at $7,700 \mathrm{~g}\left(4^{\circ} \mathrm{C}\right)$ for $15 \mathrm{~min}$ and sterilization by filtration $\left(0.22 \mathrm{~mm}\right.$ Supor $^{\circledR}$ membrane filter). BLS activity was monitored by the spot on lawn technique (3), with twofold dilutions of the supernatant in $50 \mathrm{mM}$ sodium phosphate buffer $\mathrm{pH}$ 7.0, and spotted on tryptic soy agar plates containing a lawn with the indicator strain. After incubation, the arbitrary units of activity (AU), defined as the reciprocal of the highest dilution showing inhibition of the indicator strain, were determined $(3,23)$.

Inhibitory activity of the crude BLS extract from $C$. piscicola $L 103$ against $L$. monocytogenes inoculated on fresh salmon

Salmon was obtained from a processing plant and kept frozen at $-18^{\circ} \mathrm{C}$ until use. After thawing at room temperature the skin was aseptically removed and 48 rectangular pieces were cut (approximate size $115 \times 65 \times 16 \mathrm{~mm}$ ). The pieces were placed in individual vacuum bags (Cryovac ${ }^{\circledR}$ BL-4, Grace, Santiago, Chile) and inoculated with a crude extract of the BLS at two levels of activity, $200 \mathrm{AU} \mathrm{mL}^{-1}$ and $800 \mathrm{AU} \mathrm{mL}^{-1}$. A $24 \mathrm{~h}$ culture of $L$. monocytogenes in tryptic soy broth, was added to the salmon at a final concentration of $\log 2.0 \mathrm{cfu} \mathrm{cm}^{-2}$. Following thorough massaging of the pieces in the bag to assure a good contact of the inoculum with the salmon, the fish was vacuum packaged and stored at $4 \pm 2^{\circ} \mathrm{C}$ for 15 days. An untreated control, with $0.25 \mathrm{M}$ phosphate buffer $\mathrm{pH} 7.0$, replacing the inoculum and a control containing only the indicator strain, were included for each sampling date.

At time 0 and days 5, 10 and 15, triplicate samples of each treatment were chosen for counts of L. monocytogenes on Listeria-selective agar (Oxford formulation) and MRS agar for lactic acid bacteria counts. For microbial analysis the salmon pieces were transferred to a Stomacher blender bag (Seward Medical, London, UK) containing $100 \mathrm{~mL}$ of Butterfield's phosphate buffer diluent (2) and homogenized during $2 \mathrm{~min}$ (dilution $10^{-1}$ ). Salmon $\mathrm{pH}$ was checked in the uninoculated control with a pH meter (Schott CG 840, Germany) at each sampling date. For the test, a slurry was prepared using equal 
amounts (w/v) of salmon and distilled water (heated to boiling and cooled to $\left.25^{\circ} \mathrm{C}\right)$.

For comparison of the data of bacterial growth and bacteriocin production in different culture broth and $L$. monocytogenes growth on salmon, a multifactorial analysis of variance was used. When F-values were significant, mean difference were compared using Tuckey's specific hypothesis test (95\% level of significance).

\section{RESULTS AND DISCUSSION}

\section{Growth and BLS production by $C$. piscicola $\mathrm{L} 103$ during batch fermentation}

In the three culture media $C$. piscicola $\mathrm{L} 103$ presented growth curves that showed a similar tendency, with a short lag phase of two hours, followed by a logarithmic growth phase of 10 to $12 \mathrm{~h}$ (Fig. 1). For D-MRS and mod. D-MRS higher cell densities were reached than in APT broth, which indicates less favourable growth conditions for the LAB strain in the latter broth. The observed differences could be attributed to the exhausting of some essential nutrient during the batch culture in APT (6).

The generation time for $C$. piscicola $\mathrm{L} 103$ in each broth was calculated using the optical density values $\left(\log _{10}\right)$. Results showed a generation time of $1.8 \mathrm{~h}$ in the mod. D-MRS and of 2.0 $\mathrm{h}$ in D-MRS broth, whereas in APT broth the duplication time for $C$. piscicola $\mathrm{L} 103$ was of $2.5 \mathrm{~h}$. The differences in duplication time observed confirm the presence of more favourable growth conditions for C. piscicola L 103 in both D-MRS broths, which only differ among them in their content of proteose peptone and meat extract. Thus, it is possible to point out that the

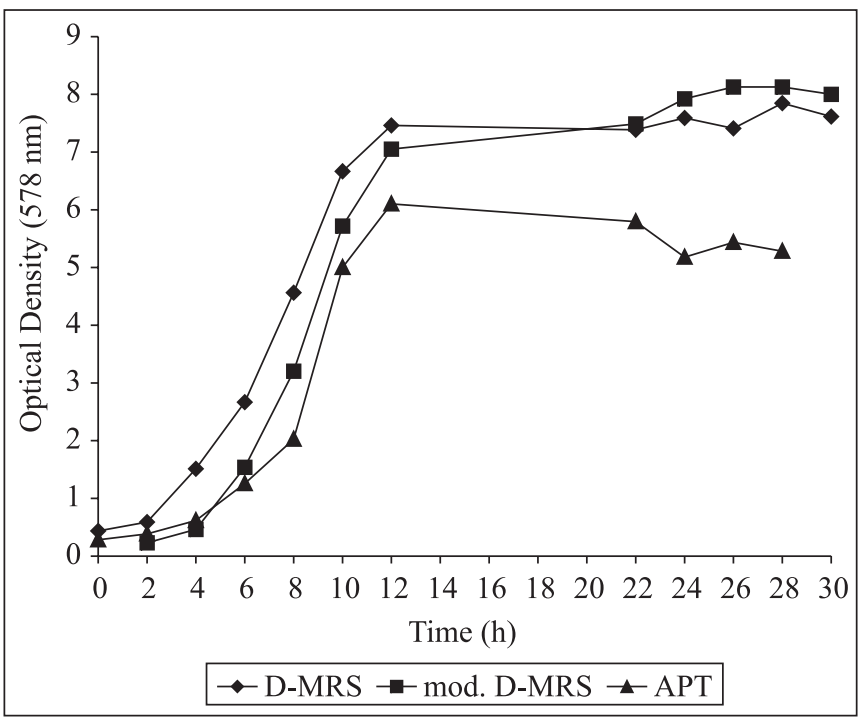

Figure 1. Growth of $C$. piscicola $\mathrm{L} 103$ in three culture broths during batch fermentation at $25^{\circ} \mathrm{C}$. proteose peptone promotes the growth of C. piscicola. Schillinger et al. (21) also reported that the presence of this peptone in the culture broth favoured the growth of C. piscicola LV 61, whereas meat- and yeast-extract were not essential.

During batch culture the BLS was produced at an earlier stage in D-MRS broth than in mod. D-MRS broth, however after $12 \mathrm{~h}$ of culture the same amount of activity was obtained in both D-MRS broths (Fig. 2). The increase in the BLS production occurred at the end of the linear growth and remained constant during the stationary phase, which has also been described for other bacteriocin $(1,4,9)$. Poor results were obtained in APT broth, where BLS production was first detected at the end of the linear growth and beginning of the stationary phase, but in a significantly lower amount $(\mathrm{p}<0.05)$ than in the other two culture media. These results are similar to those obtained by Ahn and Stiles (1) for C. piscicola LV 17 grown in APT broth, who also reported $400 \mathrm{AU} \mathrm{mL}^{-1}$ as the highest activity. They however differ from those reported for other bacteriocins, such as pediocin, nisin and amylovorin, where the presence of tryptone and yeast extract favoured the growth of the producer strains and the bacteriocin production $(9,25)$.

After $24 \mathrm{~h}$ of batch culture a decline of the activity was observed D- MRS and mod. D-MRS broth, behaviour also described for other bacteriocins during stationary growth of the producer strain $(1,4,20)$. The loss of BLS activity during stationary growth can be ascribed to a variety of factors, including a proteolytic degradation of the bacteriocin by certain proteases, adsorption of the bacteriocin molecules to the cell surface, or protein aggregation $(9,18)$.

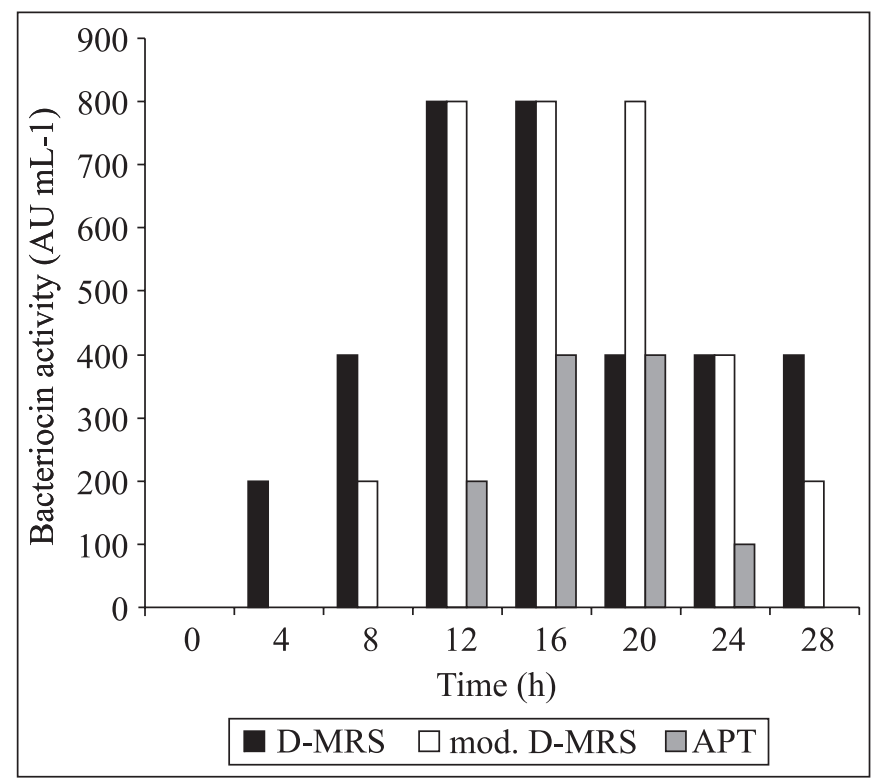

Figure 2. Arbitrary activity units $\left(\mathrm{AU} \mathrm{mL}^{-1}\right)$ of the bacteriocin like substance (BLS) from C. piscicola L 103 during batch fermentation at $25^{\circ} \mathrm{C}$ in three culture broths. 
For continuous culture the critical dilution rate in the three culture broths was calculated resulting in $0.35 \mathrm{~h}^{-1}$ for D-MRS broth, $0.39 \mathrm{~h}^{-1}$ for mod. D-MRS and $0.27 \mathrm{~h}^{-1}$ for APT broth. These values were used to calculate dilution rates I, II and III, for continuous culture, corresponding to 80,50 and $33 \%$ of the critical dilution value.

\section{Continuous culture}

During continuous fermentation, the cell density increased in the three culture media (not shown for mod. D-MRS broth), as the dilution rates increased (Fig. 3 and Fig. 4). The highest O.D. reading was obtained in APT with an O.D.578n of 9.88 (Fig. 4), which was considerably higher than during batch fermentation in the same broth. The BLS production in D-MRS and mod. DMRS broth was stimulated at the higher dilution rates, as seen in Fig. 5. At dilution rate I, an activity of $6400 \mathrm{AU} \mathrm{mL}^{-1}$ was obtained in both media, which represents a significant increase in activity, compared to the batch culture. At dilution rate II the BLS activity remained high $\left(6400 \mathrm{AU} \mathrm{mL}^{-1}\right)$ in D-MRS, while a decline occurred in mod. D-MRS broth. Different results were seen in APT broth, where the BLS production was very low, with $50 \mathrm{AU} \mathrm{mL}^{-1}$, at the three dilution rates. These values were even lower than during batch fermentation $\left(400 \mathrm{AU} \mathrm{mL}^{-1}\right)$. The high cell density and low BLS production in APT broth during continuous culture, in particular at the lowest dilution rate, could indicate that the BLS production in this broth does not occur during active cell growth, but at a later stage. This is confirmed by the results from the batch culture, where the highest BLS production was obtained after $16 \mathrm{~h}$ (Fig. 2), which corresponds to the stationary growth of C. piscicola L 103 in APT broth (Fig. 1).

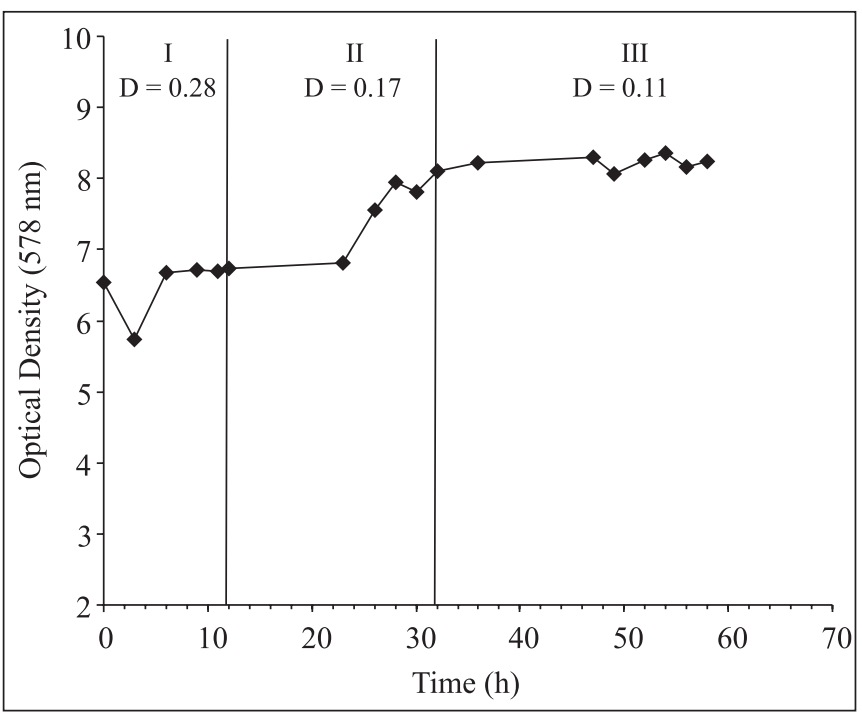

Figure 3. Continuous fermentation with varying dilution rates (D) in D-MRS broth at $25^{\circ} \mathrm{C}$ with controlled $\mathrm{pH}$ 6.5.

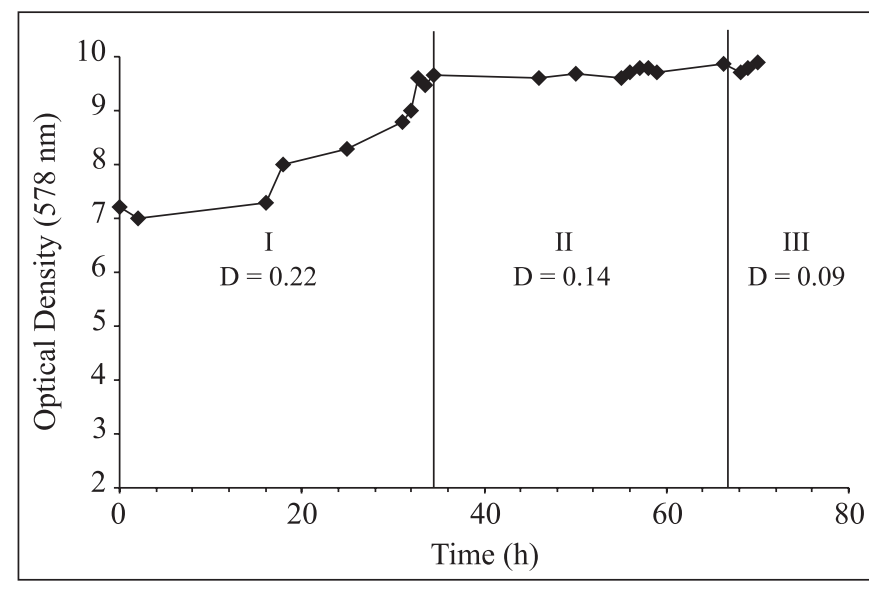

Figure 4. Continuous fermentation with varying dilution rates (D) in APT broth at $25^{\circ} \mathrm{C}$ with controlled pH 6.5.

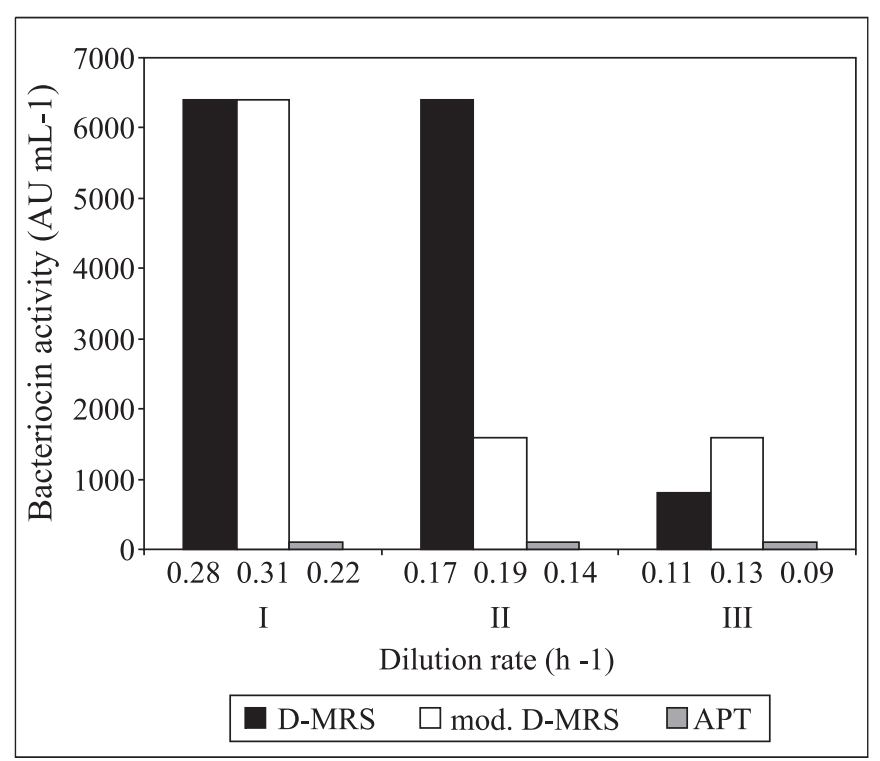

Figure 5. Bacteriocin like substance activity (BLS) production at different dilution rates during continuous culture of $C$. piscicola L 103 in D-MRS, mod. D-MRS and APT broth.

The increase in BLS production of $C$. piscicola L 103 in MRS broth at higher dilution rates is in agreement with the results from Bhugaloo-Vial et al. (4), who also observed an increase in the bacteriocin production of $C$. divergens $\mathrm{V} 41$ at higher dilution rates. On the other hand the same authors observed that the highest biomass production was obtained at the lowest dilution rate, which is also in agreement with the results of this study. This however differs for other bacteriocins $(6,8,18)$, where production was stimulated by stress factors such as low temperature, or a low dilution rate. 
Salmon inoculation for growth inhibition of $L$. monocytogenes

Results from the salmon inoculation experiment are shown in Fig. 6. During the first five days of storage at $4 \pm 2^{\circ} \mathrm{C}, L$. monocytogenes was inhibited in the presence of $800 \mathrm{AU} \mathrm{mL}^{-1}$ and counts remained at the initial inoculum level of $\log 2.0$ $\mathrm{cfu} \mathrm{cm}^{-2}$. An increase of c.a one log cycle occurred with $200 \mathrm{AU}$ $\mathrm{mL}^{-1}$, for the same period. After 15 days, counts had increased to $\log 3.8 \mathrm{cfu} \mathrm{cm}^{-2}$, in the presence of $200 \mathrm{AU} \mathrm{mL}^{-1}$ and to $\log 3.3$ cfu $\mathrm{cm}^{-2}$ with $800 \mathrm{AU} \mathrm{mL}^{-1}$. Differences among treatments with both BLS levels were not significant ( $\mathrm{p}>0.05)$. In the control without BLS, L. monocytogenes increased from $\log 2.0 \mathrm{cfu} \mathrm{cm}^{-2}$ (initial inoculum), to $\log 6.0 \mathrm{cfu} / \mathrm{cm}^{-2}$ during 15 days at $4 \pm 2^{\circ} \mathrm{C}$. These results differed significantly $(\mathrm{p}<0.05)$ from the counts obtained for the BLS inoculated salmon.

The filter sterilized, crude extract of the BLS from C. piscicola L 103 had a bacteriostatic effect against L. monocytogenes, when inoculated on salmon pieces, as no significant growth ( $p>0.05$ ) of the pathogen was observed during 15 days, as compared to the salmon inoculated only with $L$. monocytogenes (control). Other salmon inoculation experiments have also shown a bacteriostatic effect, when different strains of $C$. piscicola were co-inoculated with $L$. monocytogenes $(10,17)$, or a simulated smoked fish system (11). The direct inoculation of the crude extract of a bacteriocin will eliminate the inconvenience of the organoleptic changes that take place during growth of the producer strain. There are however, drawback such as the adsorption of the bacteriocin molecules to protein and fat

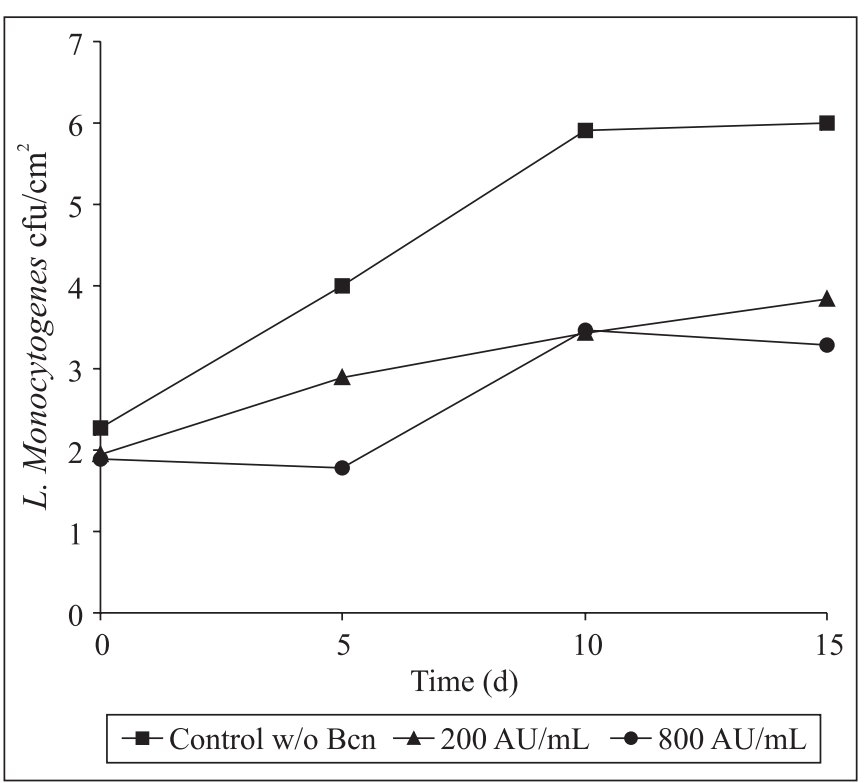

Figure 6. Inhibition of L. monocytogenes on vacuum packaged salmon inoculated with a crude extract of the bacteriocin like substance (BLS) from C. piscicola L 103, at two concentrations. particles, their inactivation by proteolytic enzymes and binding to food surfaces (8). These are probably factors that also influenced the antagonistic activity of the BLS against $L$. monocytogenes in this experiment, where only the inhibition of growth but not a complete killing effect could be achieved. The two bacteriocin levels studied showed no difference in their capability to inhibit $L$. monocytogenes in salmon. These results differ from those of other workers (24), where an increase in activity showed a greater killing capacity of the bacteriocin tested. Lactic acid bacteria in our experiment reached Log 6.0 cfu cm$~^{-2}$ after 15 days at $4 \pm 2^{\circ} \mathrm{C}$ in the three treatments, with initial counts of $\log 1.0 \mathrm{cfu} \mathrm{cm}^{-2}$ and the $\mathrm{pH}$ of the salmon flesh decreased from $6.6 \pm 0.0$ to $\mathrm{pH} 6.3 \pm 0.1$ after 15 days.

The use of a single bacteriocin such as the BLS from $C$. piscicola $\mathrm{L} 103$ is not a sufficient safety factor against $L$. monocytogenes and other strategies such as the combination of two bacteriocins $(13,20)$, or the use of factors that increase their activity $(5,15)$, will be studied. Some legal drawback must however be considered for the application of bacteriocins as safety factors in food, since up to date only nisin has been approved as a bacteriocin for use in food. The use of bacteriocin producing $\mathrm{LAB}$ cultures could be an alternative to overcome, these legal problems at the present time.

From the results of this study it was concluded that the composition of the culture broths influenced the BLS production from C. piscicola L 103. In a continuous system, with D-MRS and mod. D-MRS as culture broth, the BLS production was stimulated at the highest dilution rates, while in APT broth BLS activity was very low during continuous culture. The filter sterilized, crude extract of the BLS from C. piscicola $\mathrm{L} 103$ showed a bacteriostatic effect against $L$. monocytogenes, on vacuum packaged cold smoked salmon stored at $4 \pm 2^{\circ} \mathrm{C}$ during 15 days.

\section{ACKNOWLEDGEMENTS}

This project was supported by a grant from the Department of Research and Development, Universidad Austral de Chile (Proyect DID/UACH 200316). We gratefully acknowledge the assistance of Dr. Suzanne Hodgkinson for the english revision of this manuscript.

\section{RESUMO}

\section{Produção de substâncias semelhantes à bacteriocinas por $C$. piscicola em um sistema contínuo com três meios de cultura e seu antagonismo contra L. monocytogenes em salmão embalado a vácuo}

Três meios de cultura foram avaliados quanto a produção de substâncias semelhantes a bacteriocinas (SSB) por Carnobacterium piscicola L 103, utilizando um sistema contínuo de cultura. A eficácia da substância antagonista contra Listeria 
monocytogenes foi testada em salmão embalado a vácuo. As SSB foram produzidas em bioreator de $1.0 \mathrm{~L}$, em cultura contínua e em cultura estacionária, utilizando D-MRS, mod. D-MRS e APT como meios de cultivo. Filés de salmão foram inoculados com $\mathrm{SSB}$ (200 AU mL $\mathrm{mL}^{-1}$ e $\left.800 \mathrm{AU} \mathrm{mL}^{-1}\right)$ e L. monocytogenes $\left(8.0 \mathrm{x} 10^{1}\right.$ ufc $\mathrm{cm}^{-2}$ ) e mantidos a $4^{\circ} \mathrm{C}$. O crescimento de $L$. monocytogenes foi verificado a cada 5 dias, durante 15 dias. C. piscicola $\mathrm{L} 103$ antigiu a fase estacionária depois de $12 \mathrm{~h}$ de incubação em cultivo em batelada, sendo a atividade SSB de $800 \mathrm{AU} \mathrm{mL}^{-1}$ nos meios DMRS e mod. D-MRS e de $400 \mathrm{AU} \mathrm{mL}^{-1}$ no caldo APT. Durante a cultura continua, a atividade SSB aumentou até $6400 \mathrm{AU} \mathrm{mL} \mathrm{mL}^{-1}$ nos dois tipos de caldo MRS, ao passo que no caldo APT esta atividade diminuiu a $50 \mathrm{AU} \mathrm{mL}^{-1}$, indicando uma clara vantagem de uso dos dois primeiros meios de cultura e do sistema de crescimento contínuo. SSB mostrou efeito bacteriostático sobre L. monocytogenes quando inoculada em salmão, com contagens de $6,0 \times 10^{3}$ ufc $\mathrm{cm}^{-2}$ após 15 dias. Não foram encontradas diferenças significantes entre as duas atividades utilizadas. No ensaio controle, sem SSB, a contagem de L. monocytogenes aumentou até 1,0 x $10^{6}$ ufc $\mathrm{cm}^{-2}$ após 15 dias de estocagem.

Palavras-chave: Carnobacterium piscicola, substância semelhante à bacteriocina, antagonismo, Listeria monocytogenes, salmão embalado a vácuo

\section{REFERENCES}

1. Ahn, C.; Stiles, M.E. Plasmid-associated bacteriocin production by a strain of Carnobacterium piscicola from meat. Appl. Environ. Microbiol., 56, 2503-2510, 1990.

2. American Public Health Association. Standard Methods for the Examination of Dairy Products, $16^{\text {th }}$ edn. (Ed. R.T. Marshall). American Public Health Association Washington D.C., 1992, 546 pp.

3. Barefoot, S.; Klaenhammer, T.R. Detection and activity of Lactacin B, a bacteriocin produced by Lactobacillus acidophilus. Appl. Environ. Microbiol., 45, 1808-1815, 1983.

4. Bhugaloo-Vial, P.; Grajek, W.; Dousset, X.; Boyaval, P. Continuous bacteriocin production with high cell density bioreactors. Enzyme Microb. Technol., 21, 450-457, 1997.

5. Budu-Amoako, E.; Ablett, R.F.; Harris, J.; Delves-Broughton, J. Combined effect of Nisin and moderate heat on destruction of Listeria monocytogenes in cold-pack lobster meat. J. Food Prot., 62, 45-50, 1999.

6. Callewaert, R.; De Vuyst, L. Bacteriocin production with Lactobacillus amylovorus DCE 471 is improved and stabilized by fed-batch fermentation. Appl. Environ. Microbiol., 66, 606-613, 2000.

7. Cleveland, J.; Montville, T.J.; Nes, I.F.; Chikindas, M. 1. Bacteriocins: safe, natural antimicrobials for food preservation. Int. J. Food Microbiol., 71, 1-20, 2001.

8. De Vuyst, L. Production and applications of bacteriocins from lactic acid bacteria bioactive peptides for future food preservation. Cerevisia, 21, 71-74, 1996.
9. De Vuyst, L.; Callewaert, R.; Crabbé, K. Primary metabolite kinetics of bacteriocin biosynthesis by Lactobacillus amylovorus and evidence for stimulation of bacteriocin production under unfavourable growth conditions. Microbiology, 142, 817- 827, 1996.

10. Duffes, F.; Leroi, F.; Boyaval, P.; Dousset, X. Inhibition of Listeria monocytogenes by Carnobacterium spp. strain in a simulated cold smoked fish system stored at $4^{\circ} \mathrm{C}$. Int. J. Food Microbiol., 47, 3342, 1999.

11. Duffes, F.; Leroi, F.; Dousset, X.; Boyaval, P. Use of a bacteriocin producing Carnobacterium piscicola, isolated from fish, to control Listeria monocytogenes development in vacuum-packaged cold smoked salmon stored at $4^{\circ} \mathrm{C}$. Science des Aliments, 20, 153-158, 2000.

12. Eklund, M.W.; Poysky, F.T.; Paranjpye, R.N.; Lashbrook, L.C.; Peterson, M.E.; Pelroy, G.A. Incidence and source of Listeria monocytogenes in cold-smoked fishery products and processing plants. J. Food Prot., 58, 502-508, 1995.

13. Hanlin, M.B.; Kalchayanand, N.; Ray, P.; Ray, B. Bacteriocins of lactic acid bacteria in combination have greater antibacterial activity. J. Food Prot., 56, 252-255, 1993.

14. Jack, R.; Wan, J.; Gordon, J.; Harmark, K.; Davidson, B.; Hillier, A.; Wettenhall, R.; Hickey, M.; Coventry, J. Characterization of the chemical and antimicrobial properties of piscicolin 126, a bacteriocin produced by Carnobacterium piscicola JG126. Appl. Environ. Microbiol., 62, 2897-2903, 1996.

15. Martinis, E.; Crandall, A.; Mazzotta, A.; Montville, T. Influence of $\mathrm{pH}$, salt and temperature on nisin resistance in Listeria monocytogenes. J. Food Prot., 60, 420-423, 1997.

16. Muriana, P.M. Bacteriocins for control of Listeria spp. J. Food Prot. Suppl., 54-63, 1996.

17. Nilsson, L.; Gram, L.; Huss, H.H. Growth control of Listeria monocytogenes on cold-smoked salmon using a competitive Lactic Acid Bacteria flora. J. Food Prot., 62, 336-342, 1999.

18. O' Keeffe, T.; Hill, C. Bacteriocins. In: Encyclopaedia of Food Microbiology (Ed. Robinson). Academic Press, London, 2000, pg.183-197.

19. Peterson, M.E.; Pelroy, G.A.; Paranjpye, R.N.; Poysky, F.T.; Almond, J.S.; Eklund, M.W. Parameters for control of Listeria monocytogenes in smoked fishery products: sodium chloride and packaging method. J. Food Prot., 56, 938-943, 1993.

20. Pilet, M.F.; Dousset, X.; Barré, R.; Novel, G.; Desmazeaud, M.; Piard, J.C. Evidence for two bacteriocins produced by Carnobacterium piscicola and Carnobacterium divergens isolated from fish and active against Listeria monocytogenes. J. Food Prot., 58, 256-262, 1995.

21. Schillinger, U.; Stiles, M.E.; Holzapfel, W.H. Bacteriocin production by Carnobacterium piscicola LV 61. Int. J. Food Microbiol., 20, 131-147, 1993.

22. Schöbitz, R.; Zaror, T.; León, O.; Costa, M. A bacteriocin from Carnobacterium piscicola for control of Listeria monocytogenes in vacuum packaged meat. Food Microbiol., 16, 249-255, 1999.

23. Tagg, J.R.; Dajani, A.S.; Wannamaker, L.W. Bacteriocins of grampositive bacteria. Bacteriol. Rev., 40, 722-756, 1976.

24. Vignolo, G.; Fadda, S.; de Kairuz, M.N.; de Ruiz Holgado, A.A.P.; Oliver, G. Control of Listeria monocytogenes in ground beef by "Lactocin 705", a bacteriocin produced by Lactobacillus casei 705 . Int. J. Food Microbiol., 29, 397-402, 1996.

25. Yang, R.; Ray, B. Factors influencing production of bacteriocins by lactic acid bacteria. Food Microbiol., 11, 281-291, 1994. 